\title{
EENY, MEENY, MINY, MOE: THE RECEPTION OF RETRANSLATIONS AND HOW READERS CHOOSE
}

\author{
Mary Wardle ${ }^{1}$ \\ 1Università Sapienza di Roma, Roma, Italia
}

\begin{abstract}
One of the paradoxes of the digital age is that it has fostered small, independent enterprises alongside corporate multinationals, a trend reflected in publishing where international players co-exist on the web alongside small, independent publishers often keen to commission retranslations as 'safe bets'. Due to customers' ease of access over the Internet and sellers' low costs, book sales increasingly correspond to the 'long tail' statistical model whereby high numbers of relatively few bestsellers are sold, with the graph 'tailing off' sharply to a high number of items selling few copies. Many retranslations are often available simultaneously and, as sales are spread among them, will tend to be distributed along this tail. As online book sales increase, whether as hard copies or in digital format, when it comes to buying a translated text, customers often find themselves confronted with a choice between several different editions. This paper investigates some of the influences affecting choice, using Italian retranslations of Fitzgerald's The Great Gatsby and English retranslations of Machiavelli's The Prince as examples. Reference will be made to the shift from professional review writing to online customer appraisals and star-ratings, the presence of retranslations on bestseller lists as well as to the importance of paratextual elements such as book covers.
\end{abstract}

Keywords: Retranslation; Long Tail; Reception; Choice; Paratexts

\section{UNI DUNI TÊ: A RECEPÇÃO DA RETRADUÇÃO E COMO OS LEITORES FAZEM ESCOLHAS}

Resumo: Um dos paradoxos da era digital é que permitiu que empresas pequenas e independentes convivessem lado a lado com corporações multinacionais, uma tendência refletida no mercado editorial, onde par- 
ticipantes internacionais coexistem na web ao lado de editores pequenos e independentes, muitas vezes ávidos por encomendar retraduções como "apostas seguras". Devido ao fácil acesso dos consumidores à Internet e aos baixos preços dos vendedores, as vendas de livros correspondem cada vez mais ao modelo estatístico da "cauda longa", segundo o qual são vendidas altas quantidades de relativamente poucos bestsellers, com o gráfico despencando abruptamente devido a um alto número de itens vendendo poucas cópias. Muitas retraduções estão com frequência disponíveis simultaneamente e, como as vendas se dividem entre elas, tendem a estarem distribuídas ao longo dessa "cauda". Com o aumento das vendas online, seja de livros impressos ou em formato digital, quando se trata de comprar um texto traduzido, os compradores muitas vezes se veem defrontados com a escolha entre várias edições diferentes. $\mathrm{O}$ presente artigo investiga algumas das influências que afetam essas escolas, usando retraduções de The Great Gatsby [O grande Gatsby] de F. Scott Fitzgerald para o italiano e de $I l$ principe [O príncipe] de Machiavelli para o inglês. Faz-se referência à mudança da resenha escrita profissionalmente para as avaliações online de consumidores, bem como à importância dos elementos paratextuais, como as capas.

Palavras-chave: Retradução; Cauda longa; Recepção; Escolha; Paratextos

\section{Introduction}

Michael Cronin reminds us that translation has always been intricately linked to trade and technology. He talks of the "interconnectedness of early urban cultures" revolving around technology, trade and translation, the so-called '3T' paradigm (19) and, indeed, translation history is full of examples of reciprocal influence between the three elements, whether it be multi-lingual hard copy texts such as the Rosetta Stone, cross-cultural contacts along the Silk Road or the digital ink of today's Kindle or Google Translate.

This paper sets out to investigate the phenomenon of retranslation, and the reception of retranslations in particular, at their intersection with technology and the retail trade. In today's context, a number of retranslations can co-exist synchronically, within a statistical model defined as the 'long tail', rather than one retranslation 'taking over' from an earlier one chronologically, 
and, therefore, readers often face a choice. There is an increasing amount of academic research on the many different contexts surrounding the production of retranslations and there is discussion of translation strategies adopted across the various versions and comparative analysis of such retranslations: however, there appears to be a lack of research at present on the different factors affecting readers' choices when faced with more than one translation. By using Italian retranslations of Fitzgerald's The Great Gatsby and English retranslations of Machiavelli's The Prince as examples, the present analysis hopes to shed some light in this regard, in order to point out some factors that may influence readers.

\section{Retranslations}

Alongside the commonly cited fact that retranslations may be prompted by the need to update older versions, with the possible exception of the works termed Grandes Traductions by Antoine Berman (2), retranslations are also driven by decisions to adopt alternative translation strategies, as in the cases discussed in relation to the Retranslation Hypothesis (Koskinen and Paloposki 21 ), individual translators' new interpretations of the source text (Brownlie 167) or in response to criticism of earlier translations (Eker Roditakis 6).

Commercial concerns also represent a further spur to retranslation (Venuti 97), and, especially in the case of canonical source texts, because the end of the copyright period often heralds multiple retranslations in quick succession: for each language, almost invariably, more than one publishing company will be keen to commission a new translation as a 'safe bet' or as an indicator of prestige within their catalogue ${ }^{1}$. These are the volumes that come to comprise the publishers' backlists, or, in other words, the

\footnotetext{
${ }^{1}$ Existing translations, belonging to other publishing companies, cannot usually be used as they are themselves still under copyright.
}

Cad. Trad., Florianópolis, v. 39, n 1, p. 216-238, jan-abr, 2019. 
financial backbone of the book industry, accounting for 25 to 30 percent of the average publisher's sales: "Current titles, known as the front list, are often a gamble: they can become best sellers, but they are much more likely to disappear in a flood of returns from bookstores. By contrast, backlist books usually have predictable sales and revenues" (McDowell 12). It therefore makes economic sense for companies to commission retranslations of these books.

The situation surrounding the Italian translations of F. Scott Fitzgerald's The Great Gatsby can serve as an illustration of this phenomenon. For several decades, following the original publication of the novel in the United States in 1925, the Italian translations were few and distant in time: the first one appeared in 1936, before Fitzgerald became well-known in Italy, published in a subscription-based romantic fiction series, and it disappeared almost immediately from circulation. As the author's fame grew, a new translation was commissioned by the same publishing company, Mondadori, and it was published in 1950. This same version, with a few slight amendments is still in circulation. A further translation, aimed at the low-cost end of the market, was published nearly forty years later, in 1989. As in most similar cases, over this initial period, readers had only one or possibly two translations available at a specific moment. Once the copyright expires, however, in this case in 2011, a frantic publishing activity begins with ten translations between 2011 and 2013². In 2016, a fourteenth and fifteenth and (for now) final translations were published. While it is beyond the scope of this paper to provide a detailed analysis of these retranslations, it can be said that they fit Koskinen and Paloposki's concept of supplementarity (23), whereby each retranslation attempts to carve out its own individual niche within the market: the retranslations cover all price points, from the very cheapest (€0.99) to an expensively produced hardback edition $(€ 24.00)$; there is one edition promoted as a part of a

${ }^{2}$ F. Scott Fitzgerald died in 1940. His works entered the public domain in Europe, therefore, on 1 January 2011, 70 years after his death.

Cad. Trad., Florianópolis, v. 39, n 1, p. 216-238, jan-abr, 2019. 
series of translations carried out by 'authors' rather than 'regular' translators; one edition is printed as a parallel text with the English and Italian on opposite pages; several translations try to attract readers by adding conspicuous introductions and notes.

With all due differences, pretty much the same goes for any of the other canonical texts investigated so far in this ongoing research. The Italian retranslations of Lewis Carroll's Alice's Adventures in Wonderland, although distributed across a slightly longer time scale, follow the same pattern: after the novel's initial publication in 1865 , there are infrequent retranslations over the first seven decades, then a steady flow over the following four decades and, finally, a constant cascade in more recent times. By inverting the directionality of the translation and extending the time period even further to look at English translations of Niccolò Machiavelli's The Prince, we can observe the same phenomenon. Following the first English translation published in 1640, there is another in the seventeenth century, one in the eighteenth, four in the nineteenth, twenty-one in the twentieth and seven in the first decade of this century. Again, different retranslations emerge as appealing to different sections of the potential readership, in line with the aforementioned concept of supplementarity, proclaiming themselves by turn, in blurbs, prefaces and introductions, as editions of interest to Renaissance historians, political scientists, Italianists, or general readers (Wardle 289-90).

\section{The long tail}

This section of the paper will trace recent developments in technology and the book publishing industry in an attempt to explain how the market has adjusted to sustain such a high production of retranslations. As early as 1994, Jeff Bezos, who was to become the founder of Amazon, had an intuition that would revolutionise the book industry: he saw that what was in effect already a mature market could still represent a strong opportunity for improvement 
and growth and that this could be brought about by the then fledgling Internet. With more than 100,000 new titles published every year in the US alone and, at the time, more than 1.5 million Englishlanguage books in print, even the largest superstores could not hope to stock more than a tiny fraction of all the available titles (Anderson 49). Bezos' insight was to foresee how the Internet offered a way to break down most of the physical barriers to unlimited selection. The bricks-and-mortar superstores-such as Borders, and Barnes and Noble-that had recently sprung up had scale. They were, however, also weighed down by the economics of having to provide shelves, manage staff, run locations, and deal with a variety of factors from weather to working hours. Since then, over the last twenty years, book trading occurs increasingly online, without the constraints of physical shops and bookstore overheads.

The unlimited shelf-space of web retail, therefore, has allowed smaller publishing companies to be financially viable, concentrating more on the business of producing books, and less on their distribution and relationship with the booksellers. In the same way, more narrowly targeted goods and services have begun to be as economically attractive as mainstream fare (Anderson 52). As with many other products, niche interests can be catered for because the marketplace has become as extensive as the Internet. One of the paradoxes of the digital age, therefore, is that, rather than homogenizing the offer, in many ways, it has contributed to fostering small, independent enterprises alongside the corporate multinationals. This is reflected in the publishing industry where large international players such as Pearson, Random House and HarperCollins co-exist on the web alongside small, national, independent book publishers with limited catalogues and even more limited financial resources ${ }^{3}$.

\footnotetext{
${ }^{3}$ The UK publishing industry exemplifies the high proportion of small enterprises, with 2,255 book publishers registered for VAT as of 1 March 2016 (Office for National Statistics). 2,015 of these had revenues under $£ 1 \mathrm{~m}, 1,790$ had four or fewer employees and just fifteen had more than 250. UK Book Industry in Statistics 2016.pdf available from www.publishers.org.uk. Accessed 28 March 2018.
}

Cad. Trad., Florianópolis, v. 39, n 1, p. 216-238, jan-abr, 2019. 
The change has been profound and has occurred in a short space of time. In 1994, the year of Bezos' brainwave, over seventy percent of total fiction sales in the US were accounted for by only five authors: John Grisham, Tom Clancy, Danielle Steel, Michael Crichton and Stephen King (Sorensen 721). The table below, illustrating the collective unit sales of all the number one bestsellers over the year, highlights the dramatic loosening of the stranglehold of the bestseller over US book sales.

\begin{tabular}{|l|l|l|}
\hline & $\mathbf{1 9 9 4}$ & $\mathbf{2 0 1 1}$ \\
\hline Fiction & $19,131,339$ & $9,350,290$ \\
\hline Non-Fiction & $21,579,497$ & $10,634,449$ \\
\hline $\begin{array}{l}\text { Massmarket } \\
\text { Paperback }\end{array}$ & $43,559,794$ & $15,351,781$ \\
\hline
\end{tabular}

Table 1: drop in annual total sales for all number one bestsellers - adapted from Greco et al. (172)

The paperback figures, for example, show how the various individual chart toppers over the course of 1994 made up over 43 million sales, whereas, by 2011, that number was reduced to almost a third ${ }^{4}$. The change occurs gradually but consistently over the seventeen-year period. The figures, however, do not represent a relentless loss of readers: overall book sales in the US remain more or less constant over the same timescale. The conclusion, therefore, has to be that sales are distributed over a larger number of books.

The Pareto Principle, as applied to retail, suggests that $20 \%$ of a given company's products accounts for $80 \%$ of their sales and that this is applicable, by and large, across all product categories (Anderson 126). Book sales up until the mid-to-late nineties certainly fit into this pattern (Greco et al 171-2). With the move to

\footnotetext{
${ }^{4}$ While it is true that e-books are not included in these figures, the same source reports total sales of e-books (monitored only as of 2010) for 2011 amount to only $8,574,280$ units. See Greco et al. (172).
} 
online and digital-content businesses, however, this percentage has begun to shift radically, with demand, not only for the most popular items, but now also for products beyond the 'greatest hits' - and the list is seemingly limitless. In the case of music, figures for iTunes show that "the aggregate market for niche or 'subculture' music is effectively unbounded" and accounts for a staggering $98 \%$ of revenue (Anderson 7-8).

The resulting statistical model is what Chris Anderson has termed 'a long tail' curve where very high numbers of relatively few best-sellers are sold (usually over a short period of time, immediately after they appear on the market). The graph 'tails off' sharply then because a very high number of items sell very few copies (over a longer time span).

\section{The Long Tail}

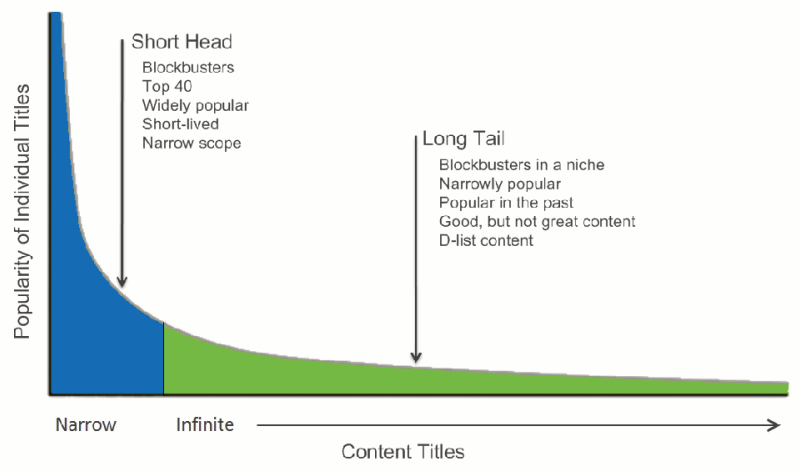

Graph 1: Typical distribution of online purchase behaviour for products such as music tracks, films and books.

Source: Learning Solutions Magazine, David Wilkins, August 17, 2009

What is interesting, from a sales point of view, is that the items distributed along the long tail, collectively, make up a market share that rivals or exceeds the relatively low number of current bestsellers and blockbusters. Some of the retranslations discussed 
above will now be out of print and only available for consultation in private collections and libraries, but simultaneously many of them are available for sale: as a result, readers have to choose and subsequent sales are divided among the various retranslations. The lower the number of copies sold for each retranslation, the further its position along the 'tail'.

A traditional bricks-and-mortar bookshop will usually stock one, perhaps two, different retranslations and most readers simply buy what they find, probably not even aware that the translation they are buying is one of several options, but an online search (Amazon being typically the first port-of-call ${ }^{5}$ ) reveals a more diverse offer. Apart from the long-out-of-print original 1936 Italian Gatsby translation, all the other fourteen versions are in fact available for sale online. Of the sixty or so Alice translations to date ${ }^{6}$, a search on Amazon Italia produces twenty-six retranslations available for sale today $^{7}$. As regards The Prince in English, for obvious reasons, the earlier printed retranslations are more difficult to track down (this topic will be discussed later), but most post-1900 retranslations are still available: from a total of thirty-five English retranslations, at least twenty appear simultaneously for sale online (Wardle 287).

\section{So how do readers / consumers choose?}

According to Barry Schwartz's 'Paradox of Choice', while life without choice is almost unbearable, variety can introduce "autonomy, control and liberation" (2). He adds that when presented with an extensive array of options, the potential

\footnotetext{
5 According to data from the Association of Italian Publishers (AIE) for 2017, Amazon is the most popular online bookstore in Italy (accessed 3 April 2018): http:// www.aie.it/Cosafacciamo/Cifreenumeridelleditoria/Mercatoeindaginidisettore.aspx 6 For ease of comparison, the present discussion includes only unabridged translations.

${ }^{7}$ Search carried out on 3 April 2018 (there are many further editions available where the translator's name does not appear).
}

Cad. Trad., Florianópolis, v. 39, nº 1, p. 216-238, jan-abr, 2019. 
customers' interest is initially aroused, but, ultimately, they seem to be overwhelmed. Factors such as hesitation take over and buyer's remorse can creep in:

... as the number of choices keeps growing, negative aspects of having a multitude of options begin to appear. As the number of choices grows further, the negatives escalate until we become overloaded. At this point, choice no longer liberates, but debilitates. It might even be said to tyrannize (2).

Research also indicates that, in the online context, when confronted with vast choice of any kind, consumers exhibit consistent behavior and look beyond the items on the first page and begin investigating all products displayed-even those that do not necessarily correspond to the initial search criteria-navigating away from mainstream markets (Anderson 8). At the click of a mouse, Amazon, for example, allows customers access to thousands of third-party bookstores selling niche editions or second-hand out-ofprint books including many of the retranslations mentioned above. While it might seem counterintuitive to offer 'shelf space' to the products of other sellers, Amazon are interested in being the chief point of reference, acting as intermediaries for other retailers and so becoming the all-containing go-to website. For the customer, there is one way in which choice can be managed: rather than all the items for sale appearing as one long indiscriminate list to scroll through, the consumer is presented with options which have been somehow ordered and ranked. While the potential customer still feels they are making individual decisions, their choices are in fact the object of influence. One, more traditional, example of this is the hit parade, chart or bestseller list model. 


\section{Bestseller lists and reviews}

In the case of books, bestseller lists, rankings and star-rating systems based on sales figures operate on at least two different levels. The first level is informational: the lists introduce or reinforce the concept of quality (leading to the equation: the higher up the list, the better the book must be). The second level is social: dealing, as they usually do, with recently published books, consumers often want to read what everyone else is reading, so that they do not feel left out of the conversation (Sorensen 718). One of the distinguishing features of a website such as Amazon, is that all books (and all other items for sale) are ranked: not just the top 10,20 or even $100^{8}$. When choosing between retranslations, therefore, the popularity of each version becomes a powerful factor in decision-making. Robert Merton describes a phenomenon he dubbed 'The Matthew Effect' (based on the Parable of the Talents in Matthew's Gospel) or Accumulated Advantage whereby the more you have, the more you get and the less you have, the less you get (Holton 510). Just as most people will opt for the full restaurant over the empty one next door, on the assumption that if so many people eat there it must be better, most customers will choose whichever comparable item is higher up in the rankings.

As well as sales figures, reviews, both negative and positive, are also influential in guiding purchasing choice (Fernandes) ${ }^{9}$. Whereas reviews of first translations tend to focus on the qualities of the source text, retranslations, typically of canonical texts, produced by large publishing companies and/or famous translators, tend to elicit comparative comments on the merits of the various

\footnotetext{
${ }^{8}$ On 2 May 2017, for example, the UK Amazon website shows the Wisehouse Classics edition of The Great Gatsby ranking as the 5,041 ${ }^{\text {st }}$ currently bestselling book as opposed to the Wordsworth edition which comes in at $250^{\text {th }}$.

${ }^{9}$ According to a survey conducted by Dimensional Research, $90 \%$ of the respondents say that positive reviews influence purchase decision, while $86 \%$ said that negative reviews affect their buying decisions. In Fernandes, Savio. Impact of Reviews and Ratings for Sellers on Amazon, 29 October 2015.
}

Cad. Trad., Florianópolis, v. 39, nº 1, p. 216-238, jan-abr, 2019. 
translations and can become the object of media attention ${ }^{10}$. The Italian retranslations of The Great Gatsby, again, offer a clear example of this as several editions appeared within a very few years of the source text coming out of copyright: in 2011, the cultural pages of national newspapers ran articles on the merits of three retranslations published that year. The same is true for the English retranslations of The Prince, with articles containing little comment on the book itself but rather concentrating on each newly published retranslation ${ }^{11}$.

Whereas in the past, reviews were largely the domain of literary critics or academic experts in the specific field and appeared, by and large, in sectorial publications to be read around the time of publication and then archived in libraries, the phenomenon has undergone radical modification with the advent of mass digitalization. Alongside these more traditional reviews, potential readers can now access, and indeed create and interact with a multitude of comments and opinions, this time written mostly by lay critics, whose reviews remain online and are universally accessible. This has led to the paradox whereby traditional paperbased publications, once considered the most permanent and stable point of reference, are rarely consulted in their original format and remain largely unread by the general public. Material posted on the Internet, on the other hand, initially seen as more transient and ephemeral, has become the accessible source, open to all

${ }^{10}$ See articles such as David Remick's “The Translation Wars: how the race to translate Tolstoy and Dostoyevsky continues to spark feuds, end friendships, and create small fortunes", The New Yorker, 7/11/2005 or Lorin Stein's article "Which Translation of Proust Should I Read", The Paris Review, 7/1/2011.

11 For Fitzgerald reviews see www.ilsole24ore.com/art/cultura/2011-06-27/ grande-gatsby-versioni-confronto-154831.shtml?uuid $=\mathrm{AapCOSjD}$ and $\mathrm{www}$. ilfattoquotidiano.it/2011/06/20/la-pivano-gli-svarioni-nel-grande-gatsby-e-tre-nuove-traduzioni/119414/ and http://ricerca.repubblica.it/repubblica/archivio/ repubblica/2011/03/30/chiedetemi-chi-era-gatsby-le-nuove-vite.html. Reviews of Machiavelli retranslations include: http://articles.latimes.com $/ 2008 / \mathrm{mar} / 30 /$ books/bk-king30 and https://www.theguardian.com/books/2009/jun/27/prince-niccolo-machiavelli-tim-parks. (all accessed 3 April 2018).

Cad. Trad., Florianópolis, v. 39, nº 1, p. 216-238, jan-abr, 2019. 
readers, whatever their interest or level of education. While this 'democratising' effect of the Internet is often evoked in a political or social context, amateur reviews influence retail behavior within the cultural sphere. When looking at Amazon product pages, Baum illustrates how, after initial attention to cover illustrations and price (more of this later), the observer's attention shifts to ratings and reviews with specific attention to the 'most useful negative review' section. This information is highly influential as, even when consumers do not purchase directly online but go to bricksand-mortar shops, they are often armed with product information sourced on the Internet.

The quality and reliability of the information provided in this format is clearly open to debate, and companies like Amazon are aware of the need to improve feedback quality: "The enhanced system will use a machine-learned model to give more weight to newer, more helpful reviews from Amazon customers. The system will continue to learn which reviews are most helpful to customers and improve the experience over time" (Bishop). Kahneman and Tversky describe how people tend to give undue weight to certain types of information, including personal anecdotes and recommendations. In outlining what they term the 'availability heuristic', the researchers explain how these personal, detailed and 'face-to-face' accounts have a greater degree of vividness and therefore sway opinions even when the same subject recognizes other sources of information as more objective and reliable (1127). The case of retranslations is one of the few instances in which the different versions appear alongside and can become the object of discussion with readers commenting on the quality of the translation. If one takes the time to read through the often apparently endless stream of feedback, there is a wealth of information from customers and, while positive reviews can sway public opinion, especially when converted into the more reductive but instant format of the five-star rating, it is not always clear how the reviewer arrives at their evaluation. With comments on Gatsby retranslations including lines such as: "I haven't read the English original but this is a 
good translation" or a book receiving a five-star rating because it was delivered quickly or because this version is lighter to carry around than another, we have to question whether this is really the best way to obtain recommendations.

The transition from the professional reviewing of books (and cultural products in general) towards crowd-sourced opinion tends to be actively encouraged by categories such as retailers, manufacturers, the media and production companies. Once consumers have bought a book, they are constantly asked for feedback and, in a further attempt to direct subsequent choices, connections are then made for them by the websites used previously, based on this information: "your recently viewed items and featured recommendations inspired by your purchases" reads an Amazon-account holder's page and, increasingly, the content that appears online is tailored according to previous searches and purchase history. Some results appear according to geographical location: running a search for English translations of The Prince on Amazon.com rather than Amazon.co.uk, for example, will elicit different results. There is, however, a high level of more individually targeted material, the product of machine learning and data mining from previous online behaviour. Perhaps more than any other large online company, Amazon devotes significant resources to its 'personalization' and 'collaborative filtering' algorithms. By capitalising on their vast trove of customer data, they also use the recommendation system to exercise their power over the industry: "When a publisher did not capitulate and the company shut off the recommendation algorithms for its books, the publisher's sales usually fell by as much as 40 percent" (Stone 302 ).

When analysing texts, Roger Chartier, one of the foremost book historians, highlights the importance of differentiating between the content and the form in which the text presents itself: "Authors do not write books. Rather they write texts which become objects copied, handwritten, etched, printed, and today computerized" (53). He goes on to observe: 


\begin{abstract}
... there is no comprehension of writing, whatever it may be, which does not depend in part upon the forms in which it comes to its reader. Hence the necessary distinction between two groups of apparatuses: those which reveal strategies of writing and the intentions of the author, and those which are a result of the publishers' decisions or the constraints of the printing house (53).
\end{abstract}

To this we must also add the influence of any decisions and constraints operated by distributors and retailers, either in physical stores or online. In his seminal work on paratexts, Gérard Genette classes any element that appears outside the physical format of the printed volume-such as correspondence, diaries or interviewsamong the elements of the epitext (344). Genette writes that paratextual elements are produced by the author, the publisher or an "authorized third party" (345), and this would appear to exclude bestseller lists, reviews and star-ratings from the discussion. He does, however, also state that the paratext can "consist [...] not of an explicit message (verbal or other) but of a fact whose existence alone, if known to the public, provides some commentary on the text and influences how the text is received" (7). Genette illustrates this category with the impact on readers of a writer's reputation or a novel winning a literary prize: although bestseller status and peer approval do not fall within the 'traditional' confines of the peritext, surely a parallel can be drawn as far as their impact on contemporary readers is concerned.

Book covers and illustrations, on the other hand, are classified as peritextual elements and also contribute to consumer choice. If we follow Ellen McCracken's argument in her discussion of electronic reading devices, these categories are in need of some degree of redefinition or 'expansion', especially now that many elements-the title, the cover design, the cover illustration, the price, a synopsis, a photograph of the author, extracts from reviews - belonging to both the epitext and the peritext appear simultaneously in one online location (106). While it is beyond the 
scope of this paper to undertake such an endeavour, the abiding influence of the physical appearance of the printed book must be emphasised. Web searches for both hard copies and digital versions of texts feature prominent cover photos whose influence is borne out by eye-tracking research into consumer behavior. When observing the product page of an online bookstore, Baum outlines how both the frequency and the intensity of the gaze are drawn first and foremost to the cover illustration, followed by other features such as the price, the author's name, and the book title.

\section{Book covers}

Any information on the front cover of a book, therefore, is highly influential, even in the online environment. The salient feature is, of course, the illustration. Although his comments refer to the role played by illustrations in literature for children, Cay Dollerup's general point is still valid when he writes:

[I]llustrations influence responses [and] become part of some kind of 'ideal tales' released in readings and they contribute substantially to narrative contracts today. . . . The draughtsmen become the equals of the translators. They take over part of the narrative contract and become co-narrators (258-9).

In the case of retranslations, it is not uncommon to find earlier outof-copyright translations appearing with contemporary artwork on the cover and recent publication dates, giving the impression of a new translation. This is particularly common with the digital texts available online to download free of charge or at low prices and lowcost printed hard copies: of the English retranslations of The Prince available through Amazon UK, it is the two 1882 retranslations by Christian Detmold or Ninian Hill Thomson and, in particular, 
W.K. Marriott's 1908 version that appear most frequently (but all with post-2010 publishing dates), rather than any of the twentysix subsequent alternatives. Each publishing company, wanting to publish their own 'new' edition of The Prince, produces their own paratextual elements - cover illustration, introduction or biographical information on the author-while the translation reproduced is one of the three listed above. On the US site, these revamped translations are even flagged explicitly as the 'bestsellers'.

There is also an established tradition of republishing previous (re)translations with stills from new audiovisual adaptations of the work, making them seem new retranslations: when Baz Luhrmann's film of The Great Gatsby was released in 2013, in Italy it was Fernanda Pivano's 1950 retranslation, and not one of the many more recent versions that appeared with images of Leonardo DiCaprio on the cover. Further examples include the 2015 English edition of War and Peace, published by BBC Books to coincide with their 2016 television adaptation. While the front cover bears images from the series and boasts "with an introduction by Andrew Davies", author of the screenplay, the translation is, in fact, that of Aylmer and Louise Maude from 1922. Again, the cover somehow creates the illusion of a new, current retranslation.

Another 'ploy' often adopted by publishing companies to help their latest retranslation emerge among other earlier versions is to add phrases such as 'now in a new translation' on the front cover: Penguin printed the caption "a gripping modern translation by Tim Parks" on the cover of their 2009 edition of The Prince, sidestepping the fact that there had been no fewer than six other English translations in the previous nine years alone ${ }^{12}$.

Most translated books make no reference on their covers to the fact that the text was originally in a different language (unless the translator is famous in their own right), adding to the impact,

12 The Translator's Note, in fact, only mentions two previous translations dating back to 1908 and 1961, leading the reader to believe that these are the most recent alternatives in English (Wardle 254).

Cad. Trad., Florianópolis, v. 39, nº 1, p. 216-238, jan-abr, 2019. 
therefore, when publishers do decide to highlight the retranslation, as in the case above. Marketing a retranslation as 'new' plays on the association whereby "new equals better, improved": the potential buyer/reader is led to infer that if this is a new translation there was possibly something lacking in the previous version(s). It somehow diminishes earlier translations. The same message can be conveyed, sometimes more subtly, in the preface, introduction or translator's note inside the volume, although few potential customers will go as far as reading this part of the book's apparatus before operating their choice. The perceived appeal of newness is so strong that, at times, publishers appear 'guilty' of giving the impression of novelty, even when marketing existing translations: 'celebrity' endorsements can be deployed on book covers to appeal to specific audiences and are sometimes used to introduce a new demographic to an otherwise little-known text. A recent English-language edition of Raymond Queneau's Exercises in Style, published in 2013, besides mentioning a foreword by Umberto Eco and an essay by Italo Calvino on the cover, highlights a quote from Philip Pullman, a far more familiar name than Queneau himself, Eco or Calvino to a younger Englishspeaking audience: "I've loved Exercises in Style for years. This translation is impeccable, extraordinary"13. The translation is the only published English translation, that of 1958 by Barbara Wright, but the use of the demonstrative adjective seems to suggest that other translations exist and that this one is better.

\section{Cost and convenience}

Online feedback left by customers on Amazon suggests that choice can also be influenced by price and convenience: is the book available in a (local) physical bookstore? How fast can it be delivered? Is it available for immediate download? Online remarks also comment on print face and paper quality as well as

${ }^{13}$ Emphasis added.

Cad. Trad., Florianópolis, v. 39, nº 1, p. 216-238, jan-abr, 2019. 
the size of the books. Customer satisfaction over these features contributes to the star-ratings, which can therefore influence the selections of further customers. There is one particular Italian Gatsby retranslation, for example, by Bruno Armando, that elicits a number of negative comments such as: "The novel is certainly a great work of literature, but the translation is disappointing. There are so many typos that it becomes unreadable"14. In this case one observes that the concept of translation is conflated with that of edition. Further evidence of this comes from other comments such as: "The parcel arrived in two days, in perfect condition. However, the translation could be slightly better, as there are some typos. But, considering that there are some (better) editions that cost 10 times as much...I'd say that this was $\square 1$ well spent" ${ }^{15}$. Although these are single examples of reviews for one individual text, they are telling and not unrepresentative in what emerges as a general awareness of translation from more extensive investigation of such material.

\section{Conclusion}

Having established that retranslations of the same source text are not necessarily separated by long periods of time, it is apparent that different publishing companies may produce and market their respective volumes contemporaneously. The 'long tail' statistical model reflected by today's book publishing industry, with specific relevance to its online presence, means that individual customers

\footnotetext{
14 "Il romanzo è certamente una grande opera letteraria, dispiace per quanto riguarda la traduzione. Purtroppo i refusi sono veramente tanti compromettendo necessariamente la lettura." Laura Aural on Amazon review 6/4/2014. My translation.

15 "Il pacchetto mi è arrivato dopo due giorni ed in perfette condizioni. Comunque, la traduzione è leggermente da migliorare, visto che ci sono alcuni errori di stampa. Anche se, considerando che ci sono edizioni (anche migliori) a prezzi 10 volte maggiori rispetto a questo... direi che l'euro di costo lo vale tutto." Francesco on Amazon review 21/8/2013. My translation.
} 
can potentially source numerous retranslations and are therefore required to make a choice.

Evidence would suggest that, although some readers will seek out specific retranslations for reasons inherently linked to what they perceive as the quality of the translation, most are influenced by combinations of 'external' factors such as availability, marketing strategies, price, prominence and distribution network of the publishing companies, star-ratings and levels of appreciation registered by fellow consumers.

Although more extensive research needs to be carried out to further identify and quantify the many elements affecting this consumer choice and reader behavior, the present paper hopes to contribute an insight into the commercialization of retranslations, especially in the online environment, and provide some information regarding the factors that affect their reception.

\section{References}

Anderson, Chris. The Longer Long Tail: how endless choice is creating unlimited demand. Random House, 2007.

Baum, Cate. "Amazon Reviews: How Readers Look at Them, and how to sell using them." Self-Publishing Review, 30 Jan. 2017, http://www.selfpublishingreview. com/2017/01/how-readers-look-at-amazon-book-pages/. Accessed 27 Oct. 2017.

Berman, Antoine. "La retraduction comme espace de la traduction." Palimpsestes 4 (1990): 1-7.

Bishop, Todd, Amazon changes its key formula for calculating product ratings and displaying reviews, 20 Jun. 2015, www.geekwire.com/2015/amazon-changes-itsinfluential-formula-for-calculating-product-ratings/. Accessed 27 Oct. 2017.

Cad. Trad., Florianópolis, v. 39, n 1, p. 216-238, jan-abr, 2019. 
Brownlie, Siobhan. "Narrative Theory and Retranslation Theory." Across Languages and Cultures 7.2 (2006): 145-170.

Chartier, Roger. "Laborers and Voyagers: from the text to the reader." Trans. J. A. González, Diacritics 22. 2, (1992): 49-61.

Cronin, Michael. Translation in the Digital Age. Routledge, 2013.

Dollerup, Cay. Tales and Translation: The Grimm Tales from Pan-Germanic Narratives to Shared International Fairytales. John Benjamins, 1999.

Eker Roditakis, Arzu. "Reviewers as Readers with Power: What a Case of Retranslation Says about Author, Translator and Reader Dynamics." Mémoires du livre 9.1 (2017): 1 - 30.

Fernandes, Savio. Impact of Reviews and Ratings for Sellers on Amazon, 29 Oct. 2015 ,

www.orderhive.com/impact-of-reviews-and-ratings-for-sellers-on-amazon/ . Accessed 27 Oct. 2017.

Fitzgerald, Francis Scott. Il grande Gatsby. Trans. Fernanda Pivano. Mondadori, 2013.

Genette, Gérard. Paratexts: Thresholds of Interpretation. Trans. Jane E. Lewin. Cambridge UP, 1997.

Greco, Albert N., Jim Milliot and Robert M. Wharton. The Book Publishing Industry 3rd ed. Routledge, 2014.

Holton, Gerard. "Robert K. Merton." American Philosophical Society 148.4 (2004): 505-517.

Kahneman, Daniel and Amos Tversky. "Judgment under Uncertainty: Heuristics and Biases.” Science 185. 4157 (1974): 1124-1131. 
Koskinen, Kaisa and Outi Paloposki. "Retranslations in the Age of Digital Reproduction.” Cadernos de Tradução 1 (2003): 19-38.

Machiavelli, Niccolò. The Prince. Trans. Tim Parks. Penguin, 2009.

McCracken, Ellen. "Expanding Genette's Epitext/Peritext Model for Transitional Electronic Literature: Centrifugal and Centripetal Vectors on Kindles and iPads." Narrative 21. 1 (2013): 105-124.

McDowell, Edwin. "The Media Business: Publishing's Backbone - Older Books." New York Times, 26 Mar. 1990.

Queneau, Raymond. Exercises in Style. Trans. Barbara Wright. Alma Classics, 2013.

Schwartz, Barry. The Paradox of Choice: why more is less. Ecco, 2016.

Sorensen, Alan T. "Bestseller Lists and Product Variety." The Journal of Industrial Economics LV. 4 (2007): 715-738.

Stone, Brad. The Everything Store: Jeff Bezos and the Age of Amazon. Corgi, 2013.

Tolstoy, Leo. War and Peace. Trans. Richard Pevear and Larissa Volokhonsky. Vintage, 2007. . War and Peace. Trans. Louise and Aylmer Maude. BBC Books, 2015.

Venuti, Lawrence. Translation Changes Everything. Routledge, 2013.

Wardle, Mary. "The Time-Travelling Prince: Machiavelli's English Journey." Between Cultures and Texts. Itineraries in Translation History. Eds. Antoine Chalvin, Anne Lange, Daniele Monticelli. Peter Lang (2011): 249-260. 
Wilkins, David. E-Learning's Long Tail: Leaving Walmart to Buy from Amazon, 17 Aug. 2009, www.learningsolutionsmag.com/articles/154/e-learnings-longtail-leaving-walmart-to-buy-from-amazon. Accessed 27 Oct. 2017.

Recebido em: 09/09/2018 Aceito em: 05/11/2018 Publicado em janeiro de 2019

Mary Wardle. E-mail: mary.wardle@uniroma1.it ORCID: https://orcid.org/0000-0002-7225-7433 